УДК 81.23

ББК 81.1

DOI: https://doi.org/10.17308/lic.2020.4/3078

\title{
МАРКЕРЫ ДИФФЕРЕНЦИАЦИИ СПОНТАННОЙ И ПОДГОТОВЛЕННОЙ ЗВУЧАЩЕЙ РЕЧИ
}

\author{
А. А. Исаева \\ Воронежский государственный университет

\section{DIFFERENTIATION MARKERS OF SPONTANEOUS AND PREPARED SPEECH}

\author{
A. A. Isaeva \\ Voronezh State University
}

\begin{abstract}
Аннотация: выявление факта спонтанности или подготовленности устного высказывания или письменного текста имеет большое теоретическое и практическое значение для решения широкого круга проблем, связанных с применением современных речевых технологий в различных сферах человеческой деятельности. Спечиалисты выделяют ряд признаков, свойственных собственно устной или письменной формам речи. Однако в отечественной практике производства фоноскопических и автороведческих экспертиз явно обозначились пограничные проблемы исследования речи, затрудняющие отнесение записанного текста к письменной или устной спонтанной или подготовленной речи. Для решения обозначенной проблемы был проведен психолингвистический эксперимент с привлечением аудиторов - носителей русского языка, владеющих английским языком на уровне C1-C2. Исследование проводилось на материале спонтанной и подготовленной звучащей речи на русском и английском языках. Исследуемые образиы принадлежали к различным функциональным стилям: литературная речь, реализующцаяся в ситуации официального общеения (устная публичная речь); литературная речь, реализующаяся в ситуачии неофицииального общения (разговорная обиходно-бытовая устная); нелитературная речь, особенности которой не являются территориально закрепленными. Изучались фрагменты репортажей, выпусков новостей, лекций, спонтанные выступления по различным вопросам - политика, спорт, экономика, экология и т. д. В результате удалось выявить квантитативные и квалитативные периептивные признаки на уровне темпа речи и паузации, которые позволяли на начальном этапе дифференцировать образць подготовленной и спонтанной речи на русском и английском языках. Материаль и результаты, полученные в ходе проведенного исследования, могут иметь практическую значимость при преподавании практики иностранных языков, риторики, судебной лингвистики, а также применяться при проведении лингвистических, автороведческих и фоноскопических экспертиз.
\end{abstract}

Ключевые слова: спонтанная речь, подготовленная речь, маркеры дифференциации, темп речи, паузация.

Abstract: the task of determining if a text or oral speech is spontaneous or prepared of great theoretical and practical significance as it can help to solve a wide range of problems associated with the use of modern speech technologies in different areas of human activity. Linguists identify a number of features inherent in oral or written language. However, specialists in the national phonoscopic and authoring expertise face boundary issues of speech research making it difficult to classify a recorded sample as written or oral spontaneous or prepared speech. To address the challenge, we conducted a psycholinguistic experiment involving auditing native Russian speakers with C1-C2 level of the English language proficiency. The research was performed on the basis of spontaneous and prepared samples of speech in Russian and English. The test samples were of different functional styles: literary speech in a situation of official communication (oral public speech); literary speech in a situation of unofficial communication (colloquial extraoccupational oral speech); non-literary speech, the features of which were not geographically specific. Excerpts of reports, news releases, lectures, spontaneous speeches on various issues -

(С) Исаева А. А., 2020

Контент доступен под лицензией Creative Commons Attribution 4.0 License.

The content is available under Creative Commons Attribution 4.0 License. 
politics, sports, economics, ecology, etc. were studied. As a result, it became possible to identify quantitative and qualitative perceptual signs at the level of speech rate and pausation, which allowed differentiating samples of prepared and spontaneous speech in Russian and English at the initial stage of speech research. The recordings and results obtained in the course of this study can be of practical importance in teaching foreign languages, rhetoric, forensic linguistics, and also can be used in linguistic, authorship and phonoscopic examinations.

Key words: spontaneous speech, prepared speech, differentiation markers, speech rate, pausation.

\section{Введение}

Установление факта спонтанности или подготовленности текста, порождаемого в устной или письменной форме, актуально и имеет большое теоретическое и практическое значение для решения широкого круга проблем, связанных с применением современных речевых технологий в различных сферах человеческой деятельности для определения факта непосредственной реакции человека, например, в криминалистике.

Специалисты, занимающиеся проведением фоноскопических, лингвистических, а также автороведческих экспертиз, выделяют ряд лингвистических особенностей, характерных для устной или письменной формы речи. Тем не менее отечественные эксперты сталкиваются с пограничными проблемами исследования речи, затрудняющими отнесение звучащего или графического текста к письменной или устной речи.

Для решения обозначенной проблемы было проведено исследование на материале звучащей речи на русском и английском языках, в ходе которой анализировались отличительные признаки устной и письменной речи, а также спонтанной и подготовленной звучащей речи.

Концепция решения проблемы заключалась в установлении на основе эмпирических данных когерентных связей единиц речи различных языковых уровней для дифференциации способов порождения спонтанной и подготовленной речи в устной ее форме на этапе семантико-синтаксического и артикуляторного программирования высказывания.

В основе исследования лежала гипотеза о возможности выявления квантитативных и квалитативных признаков спонтанной речи для установления факта подготовки устной речи и их использования в практике производства автороведческих и фоноскопических экспертиз. С этой целью был произведен психолингвистический эксперимент, в ходе которого был сформирован массив экспериментальных образцов спонтанной и подготовленной речи, принадлежащих к различным типам устной речи, представленный следующими функциональными стилями:

- литературная речь, реализующаяся в ситуации официального общения (устная публичная речь);

- литературная речь, реализующаяся в ситуации неофициального общения (разговорная обиходно-бытовая устная);
- нелитературная речь, особенности которой не являются территориально закрепленными.

Для достижения поставленной цели путем математического и перцептивного анализа был определен комплекс признаков-маркеров, во-первых, детерминирующих спонтанную устную речь, а во-вторых, позволяющих отличить один тип речи от другого по степени его подготовки.

Анализ литературных источников и изучение эмпирического материала по экспериментальному массиву текстов позволил выявить ряд статистических показателей, релевантных для дифференциации устной монологической подготовленной и спонтанной речи [1]. Теоретическую базу исследования составили труды различных ученых, лингвистов и психологов (Н. И. Жинкина, А. С. Степанова, Л. В. Бондарко и др.) [2-4], посвященные ключевым аспектам темы исследования (психологическим особенностям спонтанной и подготовленной речи, а также ее маркерам и их анализу).

При установлении факта спонтанности/подготовленности в процессе изучения монологического текста, т. е. вероятности его диктовки, чтения вслух или репродуцирования выученной наизусть «чужой речи», помимо исполнителя текста, появляется еще автор или соавтор, чье участие может быть доказано при помощи особых знаний. Поэтому установление факта подготовленной речи недостаточно свести только к разграничению ее формы на устную и письменную, поскольку обе формы речи могут иметь различную степень импровизации или подготовки. Кроме того, на сегодняшний день разграничение устной и письменной речи, а также диалогической и монологической представляют особые трудности.

Если в отношении исследования устного текста в научной и методической литературе имеются некоторые сведения, то в отношении точного определения степени подготовки письменного текста ситуация более сложная. Внимание автороведов привлекала только проблема намеренного искажения письменно-речевых навыков как фактор, затрудняющий идентификацию автора письменного текста. Однако эта задача с фактором подготовленности письменной речи не связывалась.

В то же время даже первое рассмотрение проблемы показало, что порождение речи с намеренным искажением письменно-речевого навыка требует определенной предварительной подготовки. Таким 
образом, сам факт необычных условий составления письменного текста (признаков его намеренного искажения) или конкретного способа модификации (с целью маскировки своих или имитации чужих) навыков письменной речи может указывать на предварительную подготовку продуцируемого текста.

Точно так же для маскировки собственных устно-речевых навыков или имитации речи других лиц необходима подготовка и предварительное наблюдение за наиболее броскими «своими» или «чужими» речевыми особенностями, от которых говорящий стремится либо избавиться, либо наоборот привнести в свою речь в зависимости от установки и коммуникативного намерения. Нередко необходимы актерские способности и определенные умения пародирования (имитации) речи других лиц.

Специфика текста как материализации намеренного искажения речи состоит в противоречивости ее элементов, вытекающей из того, что автор не может осознавать полностью, каким образом происходит речепорождение, что индивидуализирует его речь, а в речи других людей, как правило, обращает внимание только на отдельные, наиболее яркие, броские характеристики. Поэтому признаками, подтверждающими намеренное искажение речи, являются особенности речевого сообщения, отражающие противоречия свойств и характеристик его автора, несовместимые состояния как следствие сознательной перестройки автором документа собственных навыков письменной речи.

По данным разных исследователей выделяются такие виды искажения, как «снижение грамотности; нейтрализация индивидуальных речевых привычек; имитация речи конкретного лица, подражание стилю конкретного автора; имитация речи женщины; имитация речи мужчины; имитация речи лица пожилого возраста; имитация речи лица молодого возраста; имитация речи представителя конкретной профессиональной группы; имитация речи уголовных элементов; имитация речи, подверженной влиянию конкретного говора; имитация речи человека, находящегося в состоянии эмоционального напряженности (стресca)» и т. д. [5, с. 66]. Факт искажения речи может характеризоваться признаками безотносительно вида порождаемого текста.

Конкретные признаки могут встречаться в нескольких видах искажений, представляющих текст в виде деформированной системы устно-речевых или письменно-речевых навыков говорящего в целом, перестройку навыков речи, а также те характеристики, которые отражают противоречивые свойства личности, черты поведения или состояния автора письменного текста.

На основе выявленного комплекса признаков текст может быть определен как спонтанный, т. е. неподготовленный. При недостаточности признаков для однозначного отнесения текста к спонтанной речи будет приниматься решение о возможной ее подготовке. Поэтому далее будет необходимо выделить признаки, позволяющие устанавливать меру подготовки текста.

По мнению Е. И. Галяшиной [6], основополагающим экстралингвистическим фактором, который определяет характеристики спонтанной и подготовленной устной и письменной речи, является фактор жесткого временного ограничения в момент порождения фрагмента речи. Присутствие такого ограничения приводит к увеличению степени спонтанности, с другой стороны, его отсутствие приводит к повышению степени подготовленности текста.

Другой фактор - это использование визуального или слухового контроля порождаемого высказывания соответственно в письменной или устной форме. Наличие такого контроля повышает степень подготовленности, а отсутствие - степень спонтанности [7].

Существуют также дискурсивные слова, которые являются характерной чертой устной речи. Дискурсивные слова, испытывая процесс десемантизации, выполняют разные функции: 1) обеспечивают взаимосвязь высказываний или целых частей текста [8], в то же время подчеркивая, как он построен; 2) заполняют вынужденные в условиях спонтанной речи паузы [9]; 3) поддерживают отношения с собеседником [10]. Так, например, Ну может сигнализировать абсолютное начало текста [11] или может быть связан с переходом к другой теме [12]. Класс дискурсивных слов открытый: туда входят служебные или неполнозначные слова, модальные слова, наречия, а также частицы и некоторые выражения [13].

Дискурсивные слова, по мнению О. Б. Сиротининой, выполняют, прежде всего, организующую и заполняющую функции. Разговорная речь характеризуется сложностью планирования, синтаксис речи связан с непосредственностью общения и с диалогичностью, которые обусловливают «столь характерную для разговорной речи неполноту предложений, эллиптичность словосочетаний с массой включений» [14].

Употребление дискурсивных маркеров более характерно для устной речи; в речи письменной такие функции, как правило, выполняются знаками препинания.

Как отметила А. Н. Васильева, конкретное реальное значение этих слов определяется всецело ситуацией [15]. В лингвистике дискурсивные слова анализируются, прежде всего, в рамках конверсационного анализа с его диалогическими особенностями.

Необходимо учитывать и возрастной аспект в рассмотрении данной темы. Как было показано в 
исследованиях ряда лингвистов (см., например, для английского языка [16-18]), эти слова играют важную и специфическую роль в молодежной речи, являясь одной из ее самых ярких характеристик.

Помимо этого, существуют дискурсивные маркеры, которые характеризуют спонтанную или подготовленную речь. Например, слова-«паразиты», которые характеризуют спонтанную речь. Так, после повышения интереса к спонтанной речи в конце 60-х - начале 70-х гг. ХХ в., и в частности к явлениям речевого колебания, в литературе появился ряд терминов, таких как «незнаменательная лексика», «лишние слова» [14, с. 71-73], «nустыле частииьы» [19, с. 36], [20, с. 59], «слова-заменители» [21, с. 91] (имеются в виду заполнители пауз хезитации), однако термины эти не прижились. Кроме того, они либо слишком широки, либо слишком узки. О. Б. Сиротинина относит к «незнаменательной лексике», например, слово такой при употреблении «без опоры на признак»: «Дон Педро - это ТАКОЙ мужчина...» [9, c. 35]. А по мнению Б. Я. Ладыженской, к «вставным элементам» можно отнести не только собственно «слова», но и невербальные элементы - междометия типа «М-м-м», «э-э-э» и др. [20].

Еще одной характерной особенностью спонтанной устной речи являются нарушения плавности речевого потока, а именно возникновение повторов, самоисправлений, колебаний, самоперебивов и т. д. Эти явления часто называют «речевыми сбоями», а поскольку традиционная лингвистика ориентирована, в первую очередь, на письменный язык, они редко изучаются как самостоятельные объекты. Зачастую речевые сбои считаются помехой, «замутняющей» исходный языковой материал, доступный для линг- вистического наблюдения. В связи с этим интересно вспомнить рекомендации классика лингвистической типологии Дж. Гринберга: «Лингвист, работающий с конкретным языком, может, разумеется, сделать лишь ограниченное количество наблюдений. Этот конечный набор материала обычно называют корпусом (corpus), и он рассматривается как образец, выведенный из бесконечного множества предложений. В некоторых случаях требуется радикальная редакторская работа над корпусом. Запинки, повторения, апосиопезы, изменение конструкции в середине предложения, придание придаточному предложению статуса главного и тем самым образование предложений, кажущихся изолированными - все эти явления не принимаются во внимание...» [22; 23, р. 52]. Однако в современной лингвистике внимание уделяется даже, казалось бы, самым малым и незначительным элементам.

\section{Определение степени подготовленности устных и письменных текстов}

Итак, для дифференциации спонтанной и подготовленной речи требуется проведение тщательного анализа на основании различных признаков. Так, например, согласно Дж. Гринбергу и М. Мейлаху [24; 25], степень подготовленности устной и письменной речи можно определить с помощью ряда показателей и индексов: показателя степени общей сложности слов, показателя словосложения, показателя деривации, индекса словоизменения, индекса префиксации, индекса суффиксации, индекса флективности, индекса автосемантичности, длины фразы, лексического многообразия и т. д., что представлено в табл. 1.

Т а б ли ц а 1

Квантитативные признаки дифференциации устного и письменного текста, диалога и монолога, спонтанной и подготовленной речи

\begin{tabular}{|l|c|c|c|c|c|c|}
\hline \multirow{2}{*}{ Индекс } & \multicolumn{2}{|c|}{ Форма речи } & \multicolumn{2}{c|}{ Способ порождения речи } & \multicolumn{2}{c|}{ Характер интеракции } \\
\cline { 2 - 8 } & устная & письменная & спонтанная & подготовленная & диалог & монолог \\
\hline \multicolumn{1}{|c|}{1} & 2 & 3 & 4 & 5 & 6 & 7 \\
\hline Синтез & 2,1 & 2,9 & 2,1 & 2,8 & 2,1 & 2,3 \\
\hline Словосложение & 1,03 & 1,05 & 1,01 & 1,06 & 1,02 & 1,02 \\
\hline Деривация & 0,6 & 1,2 & 0,5 & 1,1 & 0,5 & 0,6 \\
\hline Словоизменение & 0,5 & 0,8 & 0,4 & 0,7 & 0,4 & 0,5 \\
\hline Префиксация & 0,15 & 0,3 & 0,15 & 0,31 & 0,13 & 0,17 \\
\hline Суффиксация & 0,4 & 0,8 & 0,4 & 0,7 & 0,4 & 0,47 \\
\hline Флективность & 0,4 & 0,6 & 0,4 & 0,6 & 0,4 & 0,5 \\
\hline Глагольность & 0,18 & 0,12 & 0,17 & 0,12 & 0,15 & 0,17 \\
\hline Субстантивность & 0,15 & 0,38 & 0,17 & 0,33 & 0,15 & 0,18 \\
\hline Адъективность & 0,06 & 0,12 & 0,05 & 0,13 & 0,03 & 0,05 \\
\hline Местоименность & 0,22 & 0,07 & 0,22 & 0,08 & 0,2 & 0,21 \\
\hline
\end{tabular}


О к о н ч ан и е та бл. 1

\begin{tabular}{|l|c|c|c|c|c|c|}
\hline \multicolumn{1}{|c|}{1} & 2 & 3 & 4 & 5 & 6 & 7 \\
\hline Автосемантичность & 0,43 & 0,69 & 0,44 & 0,66 & 0,43 & 0,45 \\
\hline Именительный падеж & 0,48 & 0,24 & 0,52 & 0,26 & 0,54 & 0,43 \\
\hline Родительный падеж & 0,14 & 0,34 & 0,12 & 0,3 & 0,12 & 0,17 \\
\hline Личные местоимения & 0,45 & 0,27 & 0,46 & 0,28 & 0,42 & 0,41 \\
\hline Негация & 0.036 & 0,022 & 0,04 & 0,022 & 0,046 & 0,026 \\
\hline Предикативность & 0,22 & 0,11 & 0,24 & 0,13 & 0,26 & 0,18 \\
\hline Интонационная расчлененность & 0,3 & & 0,4 & 0,18 & 0,32 & 0,2 \\
\hline Длина фразы & 7 & & 5 & 10,1 & 6 & 12 \\
\hline Лексическое разнообразие & 0,5 & 0,7 & 0,52 & 0,68 & 0,4 & 0,5 \\
\hline Лексическая тривиальность & 1,2 & 0,54 & 1,26 & 0,62 & 1,27 & 1,11 \\
\hline
\end{tabular}

Сравнение характеристик демонстрирует, что подготовленная и спонтанная речь более четко противопоставлены друг другу, чем речь устная и письменная. Публичный монолог как разновидность устной речи преимущественно формируется из подготовленных жанров.

В то же время спонтанная речь главным образом существует в форме диалога (как в устной, так и письменной форме).

Устная подготовленная речь чаще всего реализуется в виде монолога, характерного для публичного или официально-делового функционального стиля.

В свою очередь письменная подготовленная речь, по сравнению с неподготовленной письменной речью, отличается высокой степенью разнообразия лексико-грамматических средств.

Приведенные выше данные показывают, что в противопоставлении спонтанной и подготовленной устной речи маркированным членом оппозиции является именно подготовленная речь. В письменной форме речи - наоборот маркированный член оппозиции - спонтанная письменная речь, а немаркированный - подготовленная письменная речь, так как письменная форма порождения речи предопределяет присутствие хотя бы минимальной подготовки («мысленного проговаривания»).

О. Б. Сиротинина [14] предлагает следующую градацию уровней подготовленности/спонтанности устной речи (табл. 2)

Т а б ли ц а 2

Градация уровней подготовленности/спонтанности устной речи

\begin{tabular}{|c|c|c|c|}
\hline Типы устной речи & Степень подготовленности & Лингвистические признаки & $\begin{array}{c}\text { Особенности, влияние } \\
\text { на варьирование признаков }\end{array}$ \\
\hline 1 & 2 & 3 & 4 \\
\hline $\begin{array}{l}\text { Заранее подготовлен- } \\
\text { ная речь }\end{array}$ & $\begin{array}{l}\text { Чтение вслух заранее неиз- } \\
\text { вестного текста. } \\
\\
\text { Чтение вслух заранее } \\
\text { известного текста (пред- } \\
\text { варительно прочитанного } \\
\text { «про себя»). } \\
\text { Воспроизведение вслух вы- } \\
\text { ученного наизусть текста. } \\
\text { Изложение вслух письмен- } \\
\text { ного текста. }\end{array}$ & $\begin{array}{l}\text { Фонетические: } \\
\text { - стабильный темп речи; } \\
\text { - уменьшение количества семантиче- } \\
\text { ски и синтаксически не обусловлен- } \\
\text { ных пауз; } \\
\text { - высокая частотность дословных } \\
\text { повторов и дублирования реплик; } \\
\text { - ускоренная речевая реакция на } \\
\text { вопрос; } \\
\text { - соответствие логических пауз пун- } \\
\text { ктуационным паузам; } \\
\text { - диапазон методики на выделенных } \\
\text { акцентах не так велик; } \\
\text { - отсутствие пауз хезитации. } \\
\text { Лексико-грамматические: } \\
\text { - легкость деления на отдельные } \\
\text { синтагмы и предложения; } \\
\text { - стилистическая точность; } \\
\text { - сокращение кол-ва вводных и } \\
\text { незнаменательных слов. }\end{array}$ & $\begin{array}{l}\text { Особенности речевой ситу- } \\
\text { ации: } \\
\text { - целевая установка, по- } \\
\text { требностно-мотивационные } \\
\text { условия реализации речи; } \\
\text { - адресат и его роль в акте } \\
\text { общения; } \\
\text { - сложность объекта чтения; } \\
\text { - публичность чтения. }\end{array}$ \\
\hline
\end{tabular}


Продолжени е табл. 2

\begin{tabular}{|c|c|c|c|}
\hline 1 & 2 & 3 & 4 \\
\hline & $\begin{array}{l}\text { Пересказ вслух с опорой на } \\
\text { письменный текст }\end{array}$ & $\begin{array}{l}\text { Текстовые: } \\
\text { - деление на абзацы соответствует } \\
\text { письменному тексту; } \\
\text { - последовательное развитие темы }\end{array}$ & \\
\hline Квазиспонтанная речь & $\begin{array}{l}\text { Речь за суфлером. } \\
\text { Стереотипная речь по ша- } \\
\text { блонному тексту. } \\
\text { Обдуманная речь по зара- } \\
\text { нее составленному плану. } \\
\text { Репродуцирование вслух } \\
\text { «чужой» речи. } \\
\text { речевая импровизация } \\
\text { Спонтанный диалог - } \\
\text { Спонтанная монологиче- } \\
\text { ская речь. } \\
\text { Использование в устной } \\
\text { речи цитат. }\end{array}$ & $\begin{array}{l}\text { Фонетические: } \\
\text { - темповая неоднородность; } \\
\text { - усиление редукции гласных; } \\
\text { - стяжение безударных гласных в } \\
\text { один сегмент; } \\
\text { - выпадение гласных; } \\
\text { - консонантная насыщенность } \\
\text { фразы; } \\
\text { - упрощение сочетаний согласных } \\
\text { («боязнь-то есть»); } \\
\text { - преобладание просодических моде- } \\
\text { лей незавершенности; } \\
\text { - стирание внутрифразовых и } \\
\text { межфразовых границ - трудности } \\
\text { членения текста на высказывания- } \\
\text { предложения; } \\
\text { - большая мелодическая изрезан- } \\
\text { ность; } \\
\text { - большой диапазон мелодики на } \\
\text { выделенных акцентах; } \\
\text { - появление динамически неустойчи- } \\
\text { вых слов (безударных или слабоудар- } \\
\text { ных в потоке речи); } \\
\text { - макросегментация на уровне фраз, } \\
\text { фоноабзацев может быть как менее, } \\
\text { так и более дробной по сравнению } \\
\text { с макросегментацией текста при } \\
\text { чтении; } \\
\text { - сбои в функционировании речевого } \\
\text { сигнала; } \\
\text { - нарушение темпоральной (времен- } \\
\text { ной) цельнооформленности речи; } \\
\text { - появление пауз хезитации; } \\
\text { - большое количество слов-заполне- } \\
\text { ний пауз; } \\
\text { - увеличение времени интонирова- } \\
\text { ния между паузами. } \\
\text {-ентрако-грамматические: } \\
\text { - уменьшение процентного } \\
\text { соотншения официально- } \\
\text { деловой и книжной лексики; } \\
\text { - стилистические неточности, } \\
\text { повторы; } \\
\text { - замена слов, ложные начала } \\
\text { высказывания. } \\
\text { моделей; } \\
\text { - появление грамматически непра- } \\
\text { вильных конструкций; } \\
\text { - вынесение в препозицию ремы; } \\
\text { вынеение семантического }\end{array}$ & $\begin{array}{l}\text { Особенности речевой ситу- } \\
\text { ации: } \\
\text { - целевая установка, по- } \\
\text { требностно-мотивационные } \\
\text { условия реализации речи; } \\
\text { - адресат и его роль в акте } \\
\text { коммуникации; } \\
\text { - кол-во говорящих; } \\
\text { - роль речи в акте общения; } \\
\text { - сложность обсуждаемого } \\
\text { объекта; } \\
\text { - характер коммуникации, } \\
\text { публичность диалога, нали- } \\
\text { чие визуального контакта с } \\
\text { собеседником; } \\
\text { - выбор темы. }\end{array}$ \\
\hline
\end{tabular}


О кон ч ан и е та бл. 2

\begin{tabular}{|l|l|l|l|}
\hline 1 & \multicolumn{1}{|c|}{3} & \multicolumn{1}{|c|}{3} \\
\hline & & Текстовые: & \\
& & - построение текста не путем \\
логического развертывания, а путем & \\
& ассоциативног & \\
& нанизывания отдельных & \\
& высказываний; & - членение текста на абзацы \\
& может быть как более, так \\
& и менее дробным по сравнению & \\
& с членением текста при чтении & \\
\hline
\end{tabular}

Несмотря на наличие большого количества признаков дифференциации спонтанной и подготовленной речи, все они достаточно комплексные и требуют определенного количества времени для проведения анализа. Но иногда возникает необходимость в достаточно оперативном разграничении подготовленной и спонтанной речи на начальном уровне ее анализа, который мог бы осуществляться не специалистами-лингвистами, а просто образованными носителями языка или лицами, владеющими иностранным языком на достаточно высоком уровне. Поэтому была предпринята попытка выявления дифференцирующих маркеров на основе квалитативных (темпа) и квантитативных (количество пауз) перцептивных признаков речи. Для решения обозначенной проблемы был проведен психолингвистический эксперимент на материале звучащей речи на русском и английском языках, в ходе которого изучались и анализировались ряд фонетических признаков-маркеров, отличающих спонтанную и подготовленную звучащую речь.

На первом этапе происходил отбор и запись фрагментов русской и английской спонтанной и подготовленной речи длительностью каждый около 60 с. Общее время звучания фрагментов составило 2395 с (39,92 мин). Это были фрагменты выпусков новостей, а также спонтанных выступлений мужчин и женщин в возрасте от 28 до 60 лет. Отбор материала происходил по принципу общедоступности, были записаны фрагменты выпусков новостей и телепередач (интервью, опросы на улице) на различную тематику, а также лекции, при этом не учитывался пол и возраст дикторов и лекторов. Всего было записано 10 образцов спонтанной английской речи, 10 образцов подготовленной английской речи, 10 образцов русской спонтанной речи и 10 образцов русской подготовленной речи.

Затем образцы звучащей речи переводились в письменный вид (в транскрипты) с учетом заполненных хезитационных пауз. После этого был подсчитан темп речи в каждом из фрагментов. Поскольку поле исследования очень широкое, в нашем исследовании мы остановились только на фонетических маркерах спонтанной и подготовленной звучащей речи.
На втором этапе эксперимента проводилась обработка материала аудиторами в количестве 6 человек в возрасте от 23-25 лет. Это были выпускники английского отделения факультета РГФ, владеющие русским языком как родным и английским на уровне C1-C2, и ряд выпускников других факультетов ВГУ. Аудиторам было предложено прослушать предложенные фрагменты и определить, к какому виду речи (спонтанной или подготовленной) они принадлежат. Для этого им необходимо было проанализировать транскрипты по следующим параметрам: количество заполненных хезитационных пауз на 100 слогов и темп речи, который определялся как количество слогов в минуту (быстрый/средний/медленный). Пол говорящих был им известен заранее, возраст указывался примерно.

Полученные результаты анализа образцов спонтанной речи на русском и английском языках можно представить в виде таблиц (табл. 3,4 ).

Т а б ли и а 3

Темп речи и количество хезитационных пауз в спонтанных высказываниях на русском языке

\begin{tabular}{|c|c|c|c|c|}
\hline № & $\begin{array}{c}\text { Пол } \\
\text { говоря- } \\
\text { щего }\end{array}$ & $\begin{array}{c}\text { Возраст } \\
\text { говорящего }\end{array}$ & $\begin{array}{c}\text { Темп речи } \\
\text { (кол-во слогов/ } \\
\text { мин) }\end{array}$ & $\begin{array}{c}\text { Кол-во запол- } \\
\text { ненных хезита- } \\
\text { ционных пауз } \\
\text { (на 100 слогов) }\end{array}$ \\
\hline 1 & Ж & 35 & 219 & 1,8 \\
\hline 2 & Ж & 40 & 214 & 0,45 \\
\hline 3 & Ж & 35 & 211 & 0 \\
\hline 4 & Ж & 35 & 207 & 1,6 \\
\hline 5 & Ж & 35 & 190 & 1 \\
\hline 6 & $\mathrm{M}$ & 60 & 215 & 0,9 \\
\hline 7 & $\mathrm{M}$ & 35 & 331 & 2 \\
\hline 8 & $\mathrm{M}$ & 35 & 312 & 3,5 \\
\hline 9 & $\mathrm{M}$ & 35 & 288 & 1,9 \\
\hline 10 & $\mathrm{M}$ & 35 & 263 & 2 \\
\hline
\end{tabular}

Средний темп речи в спонтанных высказываниях на русском языке составил 245 слогов в мин. При этом 
самый быстрый темп наблюдался у мужчины 35 лет и составил 331 слог в мин. Самый медленный темп речи, который наблюдался у мужчины 60 лет, составил 190 слогов в мин. Среднее количество заполненных хезитационных пауз составило 1,515.

Т а б ли ц а 4

Темп речи и количество хезитационных пауз в спонтанных высказываниях на английском языке

\begin{tabular}{|c|c|c|c|c|}
\hline № & $\begin{array}{c}\text { Пол } \\
\text { говоря- } \\
\text { щего }\end{array}$ & $\begin{array}{c}\text { Возраст } \\
\text { говорящего }\end{array}$ & $\begin{array}{c}\text { Темп речи } \\
\text { (кол-во слогов/ } \\
\text { мин) }\end{array}$ & $\begin{array}{c}\text { Кол-во запол- } \\
\text { ненных хезита- } \\
\text { ционных пауз } \\
\text { (на 100 слогов) }\end{array}$ \\
\hline 1 & $\mathrm{M}$ & 40 & 204 & 1,45 \\
\hline 2 & $\mathrm{M}$ & 40 & 218 & 1,8 \\
\hline 3 & $\mathrm{M}$ & 40 & 223 & 1,4 \\
\hline 4 & $\mathrm{M}$ & 40 & 289 & 0,6 \\
\hline 5 & $\mathrm{M}$ & 50 & 239 & 1,25 \\
\hline 6 & $\mathrm{M}$ & 40 & 276 & 0,7 \\
\hline 7 & Ж & 35 & 325 & 0,25 \\
\hline 8 & $\mathrm{M}$ & 50 & 233 & 0,8 \\
\hline 9 & $\mathrm{M}$ & 40 & 255 & 0 \\
\hline 10 & $\mathrm{M}$ & 40 & 261 & 0 \\
\hline
\end{tabular}

Средний темп речи в спонтанных высказываниях на английском языке составил 252,3 слога в мин. Самый быстрый темп наблюдался у женщины 35 лет и составлял 325 слогов в мин. Самый медленный темп речи был зафиксирован у мужчины 40 лет и составлял 204 слога в мин. Среднее количество заполненных хезитационных пауз составило 0,825 .

По результатам двух таблиц, представленных выше, можно построить диаграмму, показывающую соотношение темпа английской и русской спонтанной речи (рис. 1). Диаграмма показывает, что темп английской спонтанной речи несколько превышает темп русской речи того же типа, однако это различие не существенно (8,2 слога в минуту), если принимать во внимание общие данные по темпу речи. Таким образом, можно сделать вывод о том, что в темпе английской и русской спонтанной речи существенных различий не наблюдалось.

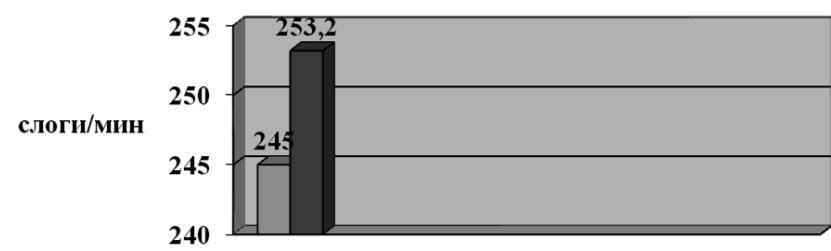

口Русская спонтанная речь $\square$ Английская спонтанная речь

Puc. 1. Сравнение темпа английской и русской спонтанной речи

\section{Анализ образцов подготовленной речи на русском языке}

Полученные результаты анализа образцов подготовленной речи на русском языке представлены в табл. 5.

Т а б ли ц а 5

Темп речи и количество хезитациионных пауз в подготовленных высказываниях на русском языке

\begin{tabular}{|c|c|c|c|c|}
\hline № & $\begin{array}{c}\text { Пол } \\
\text { говоря- } \\
\text { щего }\end{array}$ & $\begin{array}{c}\text { Возраст } \\
\text { говоря- } \\
\text { щего }\end{array}$ & $\begin{array}{c}\text { Темп речи } \\
\text { (кол-во слогов/ } \\
\text { мин) }\end{array}$ & $\begin{array}{c}\text { Кол-во запол- } \\
\text { ненных хезита- } \\
\text { ционных пауз } \\
\text { (на 100 слогов) }\end{array}$ \\
\hline 1 & Ж & 35 & 215 & 0,4 \\
\hline 2 & М & 30 & 269 & 0 \\
\hline 3 & М & 30 & 327 & 0 \\
\hline 4 & Ж & 28 & 322 & 0 \\
\hline 5 & Ж & 30 & 356 & 0,3 \\
\hline 6 & М & 35 & 368 & 0 \\
\hline 7 & Ж & 30 & 335 & 2 \\
\hline 8 & Ж & 28 & 349 & 0 \\
\hline 9 & Ж & 28 & 329 & 0 \\
\hline 10 & Ж & 30 & 355 & \\
\hline
\end{tabular}

Средний темп речи в подготовленных высказываниях на русском языке составил 322,5 слога в мин. При этом самый высокий темп наблюдался у мужчины 35 лет и составил 368 слогов в мин. Самый низкий темп речи был отмечен у женщины 35 лет и составил 215 слогов в мин. Среднее количество заполненных хезитационных пауз составило 0,27 .

\section{Анализ образцов подготовленной речи на английском языке}

Полученные результаты анализа образцов подготовленной речи на английском языке представлены в табл. 6.

Т а б ли ц а 6

Темп речи и количество хезитачионных пауз

в подготовленных высказываниях на английском языке

\begin{tabular}{|c|c|c|c|c|}
\hline № & $\begin{array}{c}\text { Пол } \\
\text { гворя- } \\
\text { щего }\end{array}$ & $\begin{array}{c}\text { Возраст } \\
\text { говоря- } \\
\text { щего }\end{array}$ & $\begin{array}{c}\text { Темп речи } \\
\text { (кол-во слогов/ } / \\
\text { мин) }\end{array}$ & $\begin{array}{c}\text { Кол-во заполнен- } \\
\text { ных хезитационных } \\
\text { пауз (на 100 слогов) }\end{array}$ \\
\hline 1 & Ж & 35 & 301 & 0 \\
\hline 2 & $\mathrm{M}$ & 30 & 313 & 0,63 \\
\hline 3 & $\mathrm{M}$ & 35 & 332 & 0 \\
\hline 4 & $\mathrm{M}$ & 35 & 301 & 0 \\
\hline 5 & $\mathrm{M}$ & 40 & 307 & 0 \\
\hline 6 & $\mathrm{M}$ & 40 & 309 & 0 \\
\hline 7 & Ж & 35 & 279 & 0 \\
\hline 8 & $\mathrm{M}$ & 45 & 317 & 0 \\
\hline 9 & $\mathrm{M}$ & 40 & 255 & 0 \\
\hline 10 & $\mathrm{M}$ & 45 & 294 & 0 \\
\hline
\end{tabular}


Средний темп речи в подготовленных высказываниях на английском языке составил 300,8 слога в мин. Самый высокий темп наблюдался у мужчины 35 лет и составил 332 слога в мин. Самый низкий темп речи был зафиксирован у мужчины 40 лет и составил 255 слогов в мин. Среднее количество заполненных хезитационных пауз составило 0,063 .

Сравнение темпа подготовленной речи на русском и английском языке также можно отразить в виде диаграммы (рис. 2).

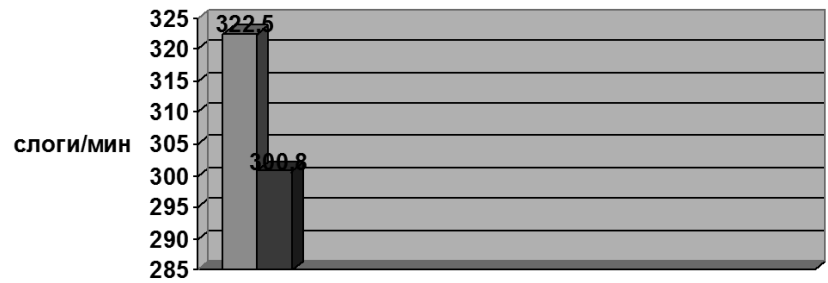

口Русская подготовленная речь $\square$ Английская подготовленная речь

Puc. 2. Сравнение темпа английской и русской подготовленной речи

Как показывает рис. 2, темп подготовленной речи на русском языке несколько выше темпа речи того же типа на английском языке, но разница небольшая $(21,7$ слога в мин), что позволяет говорить о том, что темп подготовленной речи на русском и английском языке радикально не отличаются.

Из таблиц также видно, что спонтанная речь и на русском, и на английском языках характеризуется большим количеством хезитационных пауз по сравнению с подготовленной речью соответствующего типа. Это можно объяснить тем, что, воспроизводя спонтанную речь, говорящему приходится ее обдумывать на месте, подбирать нужные слова и исправлять себя в случае ошибки, тогда как подготовленная речь этого не требует. Однако и в этом случае бывают сбои, что подтверждает наличие незначительного количества заполненных хезитационных пауз в подготовленной речи.

\section{Заключение}

Подводя итог, стоит сказать, что аудиторы отметили большое количество заполненных хезитационных пауз в спонтанной речи, также для нее оказался характерен медленный или средний темп речи. Подготовленная речь, в свою очередь, характеризовалась средним или быстрым темпом речи и меньшим количеством хезитаций. Средним темпом речи считается темп речи около 250 слогов в мин (100-120 слов/мин) [26]. Соответственно, за низкий темп речи аудиторами принималась скорость до 220 слогов в мин, а за высокий - от 280 слогов в мин и выше.
Хотелось бы отметить, что выводы по эксперименту делались, исходя из мнения большинства или всех аудиторов (там, где они совпадали) во избежание субъективности суждений.

При проведении эксперимента мы исследовали только заполненные хезитационные паузы, поскольку они являются наиболее яркими маркерами спонтанной речи.

При определении спонтанности или подготовленности текста аудиторы обращали внимание как на темп речи, так и на количество заполненных хезитационных пауз, таким образом, можно сделать вывод о том, что для отнесения речи к тому или иному виду необходим комплекс признаков, который и позволил участникам эксперимента безошибочно определить принадлежность предложенных фрагментов к образцам спонтанной или подготовленной речи.

Таким образом, подтвердилась гипотеза о возможности выявления квантитативных и квалитативных признаков спонтанной речи с целью установления факта подготовки письменной и устной речи. Выявленные квалитативные (темп речи) и квантитативные (количество заполненных хезитационных пауз на 100 слогов текста) признаки позволили определить принадлежность устной монологической речи к спонтанной или подготовленной, что было доказано аудиторами в ходе эксперимента. Они без особых затруднений определили принадлежность предоставленных им фрагментов к тому или иному виду речи (спонтанной или подготовленной), опираясь на выявленные на предварительном этапе эксперимента признаки.

Эксперимент также показал, что помимо описанных выше отличий, выявляемых лингвистами, спонтанная речь, в отличие от подготовленной, характеризуется более медленным темпом и большим количеством заполненных хезитационных пауз. Однако стоит отметить, что темп речи зависит во многом и от индивидуальных особенностей говорящего. Что касается заполненных хезитационных пауз, необходимо сказать, что они крайне редко присутствуют в подготовленной речи, это случается лишь в том случае, когда говорящий сбивается со своей мысли, теряет нить высказывания и начинает подбирать слова.

Важным является и то, что, как и было отмечено в начале нашей статьи, для правильного определения принадлежности речи к тому или иному типу недостаточно какого-то одного признака, необходим их комплекс. В нашем случае это был комплекс двух признаков (темп речи и количество заполненных хезитационных пауз на 100 слогов текста). Для эксперимента были отобраны относительно чистые образцы речи (т. е. которые можно отнести к чисто спонтанным или чисто подготовленным), поэтому двух признаков оказалось достаточно. 
Таким образом, практическая ценность проведенного исследования заключается в том, что его материалы и полученные результаты могут использоваться при преподавании практики иностранных языков, риторики, судебной лингвистики, а также применяться при проведении лингвистических, автороведческих и фоноскопических экспертиз.

\section{ЛИТЕРАТУРА}

1. Кибрик А. А., Кобозева И. М., Секерина И. А. (ред.). Современная американская лингвистика : фундаментальные направления. Изд. стереотип. M., URSS, 2016. $480 \mathrm{c}$.

2. Жинкин Н. И. Психологические особенности спонтанной речи. М. : ИЯШ, 1965. 171 с.

3. Степанов A. C. Просодические исследования спонтанной речи. М. : Просвещение, 2001. 189 с.

4. Бондарко Л. В. Спонтанная речь и организация системы языка // Бюллетень Фонетического Фонда № 8 «Фонетические свойства русской спонтанной речи»/ под ред. Л. В. Бондарко, М. Краузе. СПб., 2001. С. 17-23.

5. Россинская E. Р. Судебная экспертиза в цивилистических процессах : науч.-практ. пособие / под ред. Е. Р. Россинской. М. : Проспект, 2018. 704 с.

6. Галяшина Е. И. Установление факта предварительной подготовки письменных и устных текстов : методические рекомендации. М. : ГУ ЭКЦ МВД России, 2003. 104 c.

7. Калинин И. В. Психолингвистические исследования : звук, слово, текст. М. : Наука, 1987. 198 с.

8. Шведова Н. Ю. Очерки по синтаксису русской разговорной речи. М. : Азбуковник, 2003. 281 с.

9. Дараган Ю. В. Паразитизм или симбиоз : механизм преодоления коммуникативных сбоев и обслуживающие его вербальные средства. Труды Международного семинара «Диалог-2001» по компьютерной лингвистике и ее приложениям. Т. 1. Теоретические проблемы. Протвино, 2001. 127 с.

10. Левонтина И. Б. Русское финальное $a$ ? Портрет невидимки // Слово в тексте и в словаре : сб. ст. к семидесятилетию академика Ю. Д. Апресяна / отв. ред. Л. Л. Иомдин, Л. П. Крысин. М. : Просвещение, 2000. $148 \mathrm{c}$.

11. Лаптева О. А. Живая русская речь с телеэкрана : разговорный пласт телевизионной речи в нормативном аспекте. Изд. 7-е. M. : URSS, 2015. 520 с.

12. Касаткин Л. Л., Касаткина Р. Ф. Некоторые текстовые коннекторы в региональных и социальных разновидностях русского языка (a, но, ну) // Русский язык сегодня / отв. ред. Л. П. Крысин. М. : Просвещение, 2000. $211 \mathrm{c}$.

13. Земская $E$. A. Русская разговорная речь : Фонетика. Морфология. Лексика. Жест. М. : Наука, 1983.94 с.

14. Сиротинина О. Б. (ред.). Разговорная речь в системе функциональных стилей современного русского литературного языка : Лексика. Изд. стереотип. М. : URSS, 2016. 256 c.
15. Васильева A. Н. Частицы русской разговорной речи. Particles in colloquial Russian : Для говорящих на англ. яз. М. : Наука, 1972. 148 с.

16. Romaine P., Lange D. The use of like as a marker of reported speech and thought : a case of grammaticalization in progress // American Speech. 1991. № 66. Pp. 19-29.

17. Andersen $G$. Pragmatic markers and sociolinguistic variation : A relevance-theoretic approach to the language of adolescents. Amsterdam \& Philadelphia, 2001. 252 p.

18. Tagliamonte P. So who? Like how? Just what? Discourse markers in the conversations of Young Canadians // Journal of Pragmatics. 2005. № 34. Pp. 96-115.

19. Розанова Н. Н. Суперсегментная фонетика // Русская разговорная речь : фонетика, морфология, лексика, жест. М., 1983.

20. Ладыженская Б. Я. Особенности организации устной спонтанной речи (вставные элементы в речевом потоке) : дис. ... канд. филол. наук. М., 1985.

21. Земская E. A. Русская разговорная речь : лингвистический анализ и проблемы обучения : учеб. пособие. 5-е изд., стер. М. : ФЛИНТА, 2016. 241 с. (Русский язык как иностранный). URL: https://rucont.ru/efd/244261

22. Гринберг Дж. Антропологическая лингвистика : вводный курс. М. : URSS, 2004. 223 с.

23. Proceedings of DiSS'19, Disfluency in Spontaneous Speech Workshop. Budapest, Hungary. 12-13 September 2019. Pp. 55-67.

24. Гринберг Дж. Квантитативный подход к морфологической типологии языков. Новое в лингвистике. Вып. III. М., 1963. С. 60-94.

25. Мейлах М. Индексы морфологической типологии // Проблемы грамматического моделирования / под ред. А. А. Зализняка. М. : Наука, 1973. 155 с.

26. Что такое темп речи. URL: https://dic.academic. ru/dic.nsf/maruso/6165/\%D1\%82\%D0\%B5\%D0\%B$\mathrm{C} \% \mathrm{D} 0 \% \mathrm{BF}$

\section{REFERENCES}

1. Kibrik A. A., Kobozeva I. M., Sekerina I. A. (Eds.) Sovremennaya amerikanskaya lingvistika: Fundamentalnye napravleniya [Fundamental trends of Modern American Linguistics]. URSS. 2016. 480 p.

2. Zhinkin N. I. Psihologicheskie osobennosti spontannoj rechi [Psychological features of spontaneous speech]. Moscow: IYaSh, 1965. $171 \mathrm{p}$.

3. Stepanov A. S. Prosodicheskie issledovaniya spontannoj rechi [Prosodic studies of spontaneous speech]. Moscow: Prosveshenie, 2001. 189 p.

4. Bondarko L. V. Spontannaya rech $i$ organizaciya sistemy yazyka [Spontaneous speech and language system organization]. In Phonetic Fund Bulletin, 8 "Phonetic properties of Russian spontaneous speech". Edited by L. V. Bondarko, M. Krauze. SPb, 2001. Pp. 17-23.

5. Rossinskaya E. R. Sudebnaya ekspertiza v civilisticheskih processah: nauchno-prakticheskoe posobie [Forensic examination in civil law processes: scientific and practical guide]. Edited by E. R. Rossinskaya. Moscow: Prospekt, 2018. 704 p. 
6. Galyashina E. I. Ustanovlenie fakta predvaritelnoj podgotovki pismennyh i ustnyh tekstov: Metodicheskie rekomendacii [Methodology for establishing the fact of preliminary preparation of written and oral texts]. Moscow: Main Directorate of the Criminal Expertise Centre of RF MIA, 2003. $104 \mathrm{p}$.

7. Kalinin I. V. Psiholingvisticheskie issledovaniya: zvuk, slovo, tekst [Psycholinguistic study: a sound, a word, a text]. Moscow: Nauka, 1987. 198 p.

8. Shvedova N. Yu. Ocherki po sintaksisu russkoj razgovornoj rechi [Essays on the syntax of Russian colloquial speech]. Moscow: Azbukovnik, 2003. 281 p.

9. Daragan Yu. V. Parazitizm ili simbioz: mehanizm preodoleniya kommunikativnyh sboev i obsluzhivayushie ego verbalnye sredstva [Parasitism or symbiosis: a mechanism for overcoming communication failures and the verbal means serving it]. In Proceedings of International Workshop Dialogue '2001 on Computational Linguistics and its Applications. Volume 1. Theoretical problems. Protvino, 2001. $127 \mathrm{p}$.

10. Levontina I. B. Russkoe finalnoe a? Portret nevidimki [Russian final $a(e h)$ ? Portrait of an invisible man]. In: Word in the text and in the dictionary. Collection of articles dedicated to the seventieth birthday of Academician Yu. D. Apresyan. Main editor L. L. Iomdin, L. P. Krysin. Moscow: Prosveshenie, 2000. 148 p.

11. Lapteva O. A. Zhivaya russkaya rech s teleekrana: Razgovornyj plast televizionnoj rechi v normativnom aspekte [Live Russian Speech on TV: Colloquial TV Speech in Normative Aspect]. Ed. 7 URSS. 2015. 520 p.

12. Kasatkin L. L., Kasatkina R. F. Nekotorye tekstovye konnektory $v$ regionalnyh $i$ socialny h raznovidnostyah russkogo yazyka (a, no, nu) [Some text connectors in regional and social varieties of the Russian language (ah, but, well)]. In: Russian language today. Main editor L. P. Krysin. Moscow: Prosveshenie, 2000. 211 p.

13. Zemskaya E. A. Russkaya razgovornaya rech. Fonetika. Morfologiya. Leksika. Zhest [Russian Colloquial Speech: Phonetics. Morphology. Vocabulary. Gesture]. Moscow: Nauka, 1983. 94 p.

14. Sirotinina O. B. (Eds.) Razgovornaya rech $v$ sisteme funkcionalnyh stilej sovremennogo russkogo literaturnogo yazyka: Leksika [Conversational speech in the system of functional styles of the modern Russian literary language: Vocabulary]. Ed. stereot. URSS. 2016. $256 \mathrm{p}$.

Воронежский государственный университет

Исаева А. А., кандидат филологических наук, преподаватель кафедры перевода и профессиональной коммуникации

E-mail: anna.isaeva@gmail.com

Поступила в редакциюю 18 августа 2020 г.

Принята к публикаџии 25 сентября 2020 2.
15. Vasileva A. N. Chasticy russkoj razgovornoj rechi. Particles in colloquial Russian: Dlya govoryashih na angl. yaz. [Particles in colloquial Russian: for English speakers]. Moscow: Nauka, 1972. 148 p.

16. Romaine P., Lange D. The use of like as a marker of reported speech and thought: a case of grammaticalization in progress. American Speech. 1991. No. 66. Pp. 19-29.

17. Andersen G. Pragmatic markers and sociolinguistic variation: A relevance-theoretic approach to the language of adolescents. Amsterdam \& Philadelphia, 2001. 252 p.

18. Tagliamonte P. So who? Like how? Just what? Discourse markers in the conversations of Young Canadians. Journal of Pragmatics. 2005. No. 34. Pp. 96-115.

19. Rozanova N. N. Supersegmentnaya fonetika. Russkaya razgovornaya rech: fonetika, morfologiya, leksika, zhest [Suprasegmental phonetics. Russian colloquial speech: phonetics, morphology, vocabulary, gesture]. Moscow, 1983.

20. Ladyzhenskaya B. Ya. Osobennosti organizacii ustnoj spontannoj rechi (vstavnye elementy $v$ rechevom potoke) [Features of oral spontaneous speech organization (expletives in the voice stream)]. PhD thesis in Linguistics. Moscow, 1985.

21. Zemskaya E. A. Russkaya razgovornaya rech: lingvisticheskij analiz i problemy obucheniya [Russian colloquial speech: linguistic analysis and learning problems [Electronic resource]: teaching guide. 5th ed., ster. Moscow: FLINTA, 2016. 241 p.] (Russian as a foreign language). Available at: https://rucont.ru/efd/244261

22. Greenberg J. Antropologicheskaya lingvistika: Vvodnyj kurs [Anthropological Linguistics: an Introduction]. Moscow: URSS, 2004. 223 p.

23. Proceedings of DiSS'19, Disfluency in Spontaneous Speech Workshop. Budapest, Hungary. 12-13 September 2019. Pp. 55-67.

24. Greenberg J. Kvantitativnyj podhod $k$ morfologicheskoj tipologii yazykov [A Quantitative Approach to the Morphological Typology of Language]. In New in linguistics. Issue III. Moscow, 1963. Pp. 60-94.

25. Mejlah M. Indeksy morfologicheskoj tipologii. Problemy grammaticheskogo modelirovaniya [Indexes of morphological typology. Problems of grammatical modeling]. Edited by A. A. Zaliznyak. Moscow: Nauka, 1973. $155 \mathrm{p}$.

26. Chto takoe temp rechi [What is the rate of speech]. Available at: https://dic.academic.ru/dic.nsf/maruso/6165/\%D1\%82\%D0\%B5\%D0\%BC\%D0\%BF

Voronezh State University

Isaeva A. A., Candidate of Philology, Lecturer of the Translation and Professional Communication Department E-mail:anna.isaeva@gmail.com

Received: 18 August 2020

Accepted: 25 September 2020 


\section{Для цитирования:}

Исаева А. А. Маркеры дифференциации спонтанной и подготовленной звучащей речи // Вестник Воронежского государственного университета. Серия: Лингвистика и межкультурная коммуникация. 2020. № 4. C. 37-48. DOI: https://doi.org/10.17308/lic.2020.4/3078

\section{For citation:}

Isaeva A. A. Differentiation markers of spontaneous and prepared speech. Proceedings of Voronezh State University. Series: Linguistics and Intercultural Communication. 2020. No. 4. Pp. 37-48. DOI: https://doi.org/10.17308/ lic. $2020.4 / 3078$ 